\title{
Rhizobium leguminosarum contains multiple chaperonin (cpn60) genes
}

\author{
Emma J. Wallington and Peter A. Lund \\ Author for correspondence: Peter A. Lund. Tel: +4421 414 5583. Fax: + 44214146557 \\ e-mail: p.a.lund@uk.ac.bham
}

School of Biological Sciences, University of Birmingham, Birmingham B15 2TT, UK

\begin{abstract}
We have examined the heat shock response of Rhizobium leguminosarum. After normal growth at $28^{\circ} \mathrm{C}$, a 10 min heat shock at $37^{\circ} \mathrm{C}$ induced the synthesis of proteins with approximate $M_{r}$ values of $90000,70000,60000$, 58000, 19000, 17000 and 13000 . A monoclonal antibody raised against the E. coli Cpn60 cross-reacted with proteins of $M_{r} 60000$ and 58000 in $R$. leguminosarum, suggesting that both were Cpn60 homologues. Hybridization of an E. coli cpn60 probe to total DNA from Rhizobium leguminosarum also showed evidence for at least two cpn60 homologues. One of these was cloned and completely sequenced, and showed close homology to cpn60 sequences from other prokaryotes. The expression of this gene in $E$. coli failed to complement a cpn60 mutation, either for growth at high temperature or for growth of bacteriophage $\lambda$. Hybridization of total $R$. leguminosarum DNA with a probe from this gene revealed the presence of a third putative cpn60 gene. Two further hybridizing clones were analysed and found to consist of two additional cpn60 sequences plus upstream regions containing putative cpn10 genes.
\end{abstract}

Keywords: Rbizobium leguminosarum, molecular chaperones, heat-shock response, cpn60, groEL

\section{INTRODUCTION}

All organisms show a conserved response to stresses such as heat shock, characterized by the induction or elevated synthesis of a set of specific proteins (Lindquist \& Craig, 1988). Much interest is currently centred on the properties and roles of these proteins, several of which appear to act as molecular chaperones, assisting other proteins to attain their final correctly folded and active structure (Ellis \& van der Vies, 1991; Gething \& Sambrook, 1992). A subclass of the molecular chaperone proteins is typified by the essential GroEL protein of E. coli, which is present in the cell as a complex of 14 subunits, each of $M_{\mathrm{r}} 57000$ (Zeilstra-Ryalls et al., 1991). Proteins which are in the same family as the GroEL protein are referred to as chaperonins, or Cpn 60 proteins. Cpn60 protein interacts in vivo and in vitro with the Cpn10 (GroES) protein (Ellis \& van der Vies, 1991; Zeilstra-Ryalls et al., 1991). Of the 33 bacterial species for which complete $\operatorname{cpn} 60$ sequences have been reported in the GenBank and EMBL databases

The GenBank accession number for the sequence data reported in this paper is L20775. (up to July 1993), 28 are reported as having only one copy of this gene. However, several Streptomyces species, Mycobacterium tuberculosis and M. leprae, Rbizobium meliloti, Bradyrbizobium japonicum and Synechocystis sp. PCC 6803 have been shown to have two or more copies of the $c p n 60$ genes (Guglielmi et al., 1991; De Wit et al., 1992; Kong et al., 1993; Rusanganwa \& Gupta, 1993; Fischer et al., 1993; Lehel et al., 1993). The functional significance of these multiple copies is unknown. In vitro, Cpn60 can bind to a wide variety of proteins, including bacterial ribulose bisphosphate carboxylase (Goloubinoff et al., 1989), pre$\beta$-lactamase (Laminet et al., 1990), nitrogenase (Govezensky et al., 1991), citrate synthase (Buchner et al., 1991), rhodanese (Mendoza et al., 1991), dihydrofolate reductase (Viitanen et al., 1991), $\alpha$-glucosidase (Holl-Neugebauer $e t$ al., 1991), lactate dehydrogenase (Badcoe et al., 1991), glutamine synthetase (Fisher, 1992), and several thermophilic enzymes (Taguchi et al., 1991). Polypeptides which vary greatly in their final size, shape, function or cellular location interact with Cpn60; about half of the proteins in E. coli have been shown to be capable of interacting with E. coli Cpn60 (Viitanen et al., 1992). The details of the precise role of Cpn60 in vivo are not clear but it appears to act in enabling proteins to fold correctly into their final 
active conformation, either after de novo synthesis or following damage by heat shock or similar stresses (Zeilstra-Ryalls et al., 1991; Saibil \& Wood, 1993). As this function and wide range of binding specificity is provided by a single gene product in most organisms, the presence of multiple $\operatorname{cpn} 60$ genes in a few bacteria is unexpected.

In the current study we present evidence suggesting that $R$. leguminosarum possesses at least three copies of the $c p n 60$ gene, and that at least two Cpn60 proteins are expressed. The possible significance of this with respect to nodulation and nitrogen fixation is discussed.

\section{METHODS}

Bacterial strains and culture conditions. $R$. leguminosarum isogenic strains $8401 /$ pRL1 (bv. viciae), 8002 (bv. phaseoli) and $8401\left(\mathrm{sym}^{-}\right)$were grown at $28^{\circ} \mathrm{C}$ in a complete medium (Beringer, 1974). For $\left[{ }^{35} \mathrm{~S}\right]$ methionine pulse labelling experiments, the cells were grown in minimal Y media (Sherwood, 1970). In both cases streptomycin was added to a final concentration of $100 \mu \mathrm{g} \mathrm{ml}^{-1}$. E. coli SF103 contains a cpn60 ts mutation and was used in the complementation experiments. This strain was constructed by P1 transduction of the cpn60 44 mutation from CG2241 (C. Georgopoulos) into TG1 [supE lisd $\Delta 5$ thi $\Delta($ lac-pro $A B) \mathrm{F}^{\prime}$ (traD pro $A B^{+}$lac $I^{\mathrm{q}}$ lac $\left.Z \Delta \mathrm{M} 15\right)$; S. Fowell, pers. comm.]. E. coli TG2 [TG1 containing $\Delta(\operatorname{sr} l-\operatorname{rec} A) 306:: \operatorname{Tn} 10 ; \mathrm{T}$. Gibson pers. comm.] was used as the host strain for cloning and sequencing experiments. E. coli strains were grown in Luria broth (Sambrook et al., 1989). The plasmid vector pSU9 (Martinez et al., 1988) was used in cloning experiments, and was maintained in cultures by chloramphenicol selection $\left(50 \mu \mathrm{g} \mathrm{ml}^{-1}\right)$. IPTG was added to a final concentration of $0.1 \mathrm{mM}$ in complementation experiments. The lysogenic E. coli strain ATCC 10798 was used to prepare a $\lambda$ lysate for the phage growth experiments. Preparation methods for the $\lambda$-lysate and TB media were as described by Silhavy $e t a l$. (1984).

Assessment of $\lambda$ growth. E. coli strains TG1, or SF103 harbouring various plasmids were mixed with dilutions of the $\lambda$ lysate and plated onto TB agar in TB overlay. Both the E. coli Cpn60 and the R. leguminosarum $\mathrm{C} 15$ gene were expressed from the lac promoter in pSU-based plasmids. $\lambda$ growth was assessed both in the presence and absence of IPTG by scoring plaques after overnight incubation.

Protein labelling in heat shocked cells. Cultures were grown to early exponential phase in a methionine free medium (minimal $\mathrm{Y})$ at $28^{\circ} \mathrm{C}$. Aliquots $(0.5 \mathrm{ml})$ were heat shocked at $37^{\circ} \mathrm{C}$ or $45^{\circ} \mathrm{C}$ for $10 \mathrm{~min}$ and $5 \mu \mathrm{Ci}(185 \mathrm{kBq})\left[{ }^{35} \mathrm{~S}\right]$ methionine (translabel, ICN) was added for $20 \mathrm{~min}$, before pelleting the cells by centrifugation $(13000 \mathrm{~g}, 5 \mathrm{~min})$ in a microfuge, and washing excess label away with non-radioactive medium. Cells were resuspended in $50 \mu \mathrm{l}$ SDS-PAGE sample buffer, and boiled briefly. Equal volumes were electrophoresed on SDS-PAGE gels, using a Bio-Rad Mini Protean II system. Gels were dried before autoradiography, and autoradiographs were scanned using an Ultro-Scan laser densitometer (LKB).

Protein $\mathbf{N}$-terminal analysis. This was carried out by Alta Bioscience, University of Birmingham. Proteins were separated by SDS-PAGE, electroblotted onto PVDF membrane and stained with PAGE Blue 83. The band of interest was excised and subjected to Edman degradation.

Immunoblotting. Proteins were detected, following separation by SDS-PAGE and electroblotting onto nitrocellulose, with a monoclonal antibody (IA1) raised against $M$. bovis, which crossreacts well with E. coli Cpn60 (J. de Bruyn pers. comm.) or a monoclonal antibody $(4-3 F)$ raised against $E$. coli $C p n 60$ (A. Ivic, pers. comm.). Bound antibody was detected using 4chloro-1-naphthol via an anti-mouse horseradish peroxidase conjugate.

Immunoprecipitation. Cells were grown up, heat shocked and pulse chased with $\left[{ }^{35} \mathrm{~S}\right]$ methionine as described above. The labelled cells were then centrifuged, the pellet washed with PBS, and resuspended in $125 \mu \mathrm{l}$ TES $(50 \mathrm{mM}$ Tris/HCl, $\mathrm{pH} 8 \cdot 0$, $5 \mathrm{mM}$ EDTA, $20 \%$, w/v, sucrose plus $600 \mu \mathrm{g}$ lysozyme $\mathrm{ml}^{-1}$ ), and incubated on ice for $30 \mathrm{~min}$. Equilibration buffer $(375 \mu \mathrm{l})$ ( $50 \mathrm{mM}$ Tris/ $\mathrm{HCl}, \mathrm{pH} 8.0,66 \mathrm{mM}$ EDTA, $200 \mathrm{mM} \mathrm{KCl}$ ) was added, and the cells were lysed by three cycles of freeze-thawing in liquid nitrogen. Cell debris was pelleted by centrifugation at $13000 \mathrm{~g}$ for $10 \mathrm{~min}$ at $4{ }^{\circ} \mathrm{C}$. A $100 \mu \mathrm{l} \mathrm{vol}$. of the supernatant was precleared for $1 \mathrm{~h}$ on ice with $100 \mu \mathrm{lGF} 6$ (a monoclonal antibody raised against Helicobacter pylori flagella sheath, a gift from C. Luke and C. Penn) to remove proteins which bound non-specifically to $\operatorname{Ig} G$ molecules, the immune complex being removed by incubation with Protein A as described below. A $100 \mu \mathrm{l}$ vol. of $4-3 \mathrm{~F}$ monoclonal antisera was then added, and incubation was continued on ice for $1 \mathrm{~h} ; 100 \mu \mathrm{l}$ protein A (BRL) was then added and the immune complex removed by centrifugation $\left(13000 \mathrm{~g}, 10 \mathrm{~min}, 4^{\circ} \mathrm{C}\right)$. The pellet was washed three times in PBS and resuspended in $50 \mu \mathrm{l}$ SDS-PAGE buffer.

Analysis of total DNA. Total DNA was prepared using a proteinase $\mathrm{K}$ /cetyltrimethylammonium bromide method (Ausubel, 1987). Southern blots were prepared and hybridized as described (Sambrook et al., 1989), with washing steps being carried out to high stringency $\left(1 \times \mathrm{SSPE}, 0 \cdot 1 \% \mathrm{SDS}, 42{ }^{\circ} \mathrm{C}\right)$. ${ }^{32} \mathrm{P}$-labelled probes were prepared using random oligonucleotide primed synthesis of isolated restriction fragments (Sambrook et al., 1989).

Cloning strategy and sequence determination of $R$. leguminosarum cpn60 homologues. Total DNA from R. leguminosarum strain $8401 / \mathrm{pRL} 1$ was digested with EcoRI, and size fractionated on a $0.6 \%$ agarose gel. The $2.5-4 \mathrm{~kb}$ region was purified from a gel, ligated into the vector pSU9 and transformed into TG2 cells. Plasmids containing inserts that hybridized with a probe containing the E. coli cpn60 gene were identified by digestion with EcoRI and Southern blotting. Sequence determination of the insert DNA was carried out using a Sequenase kit (United States Biochemicals), using double-stranded DNA and the M13 universal and reverse primers, as described by Del Sal et al. (1989). Subcloning the $3.5 \mathrm{~kb}$ EcoRI fragment into the vector pGEM $7 \mathrm{zf}(+)$ allowed the creation of nested deletion series in both orientations using the Erase-a-Base system (Promega), such that both strands of the cpn60 ORF could be sequenced. Specific oligonucleotide primers were synthesized (Alta Bioscience) to complete the sequence.

Similarly, a 4-6 kb PstI library was produced from PstI-digested size fractionated $R$. leguminosarum total DNA and analysed for hybridizing sequences using the EcoRI fragment cloned as described above. Two hybridizing plasmids were identified by hybridization, and the DNA sequence of the inserts was partially determined. 


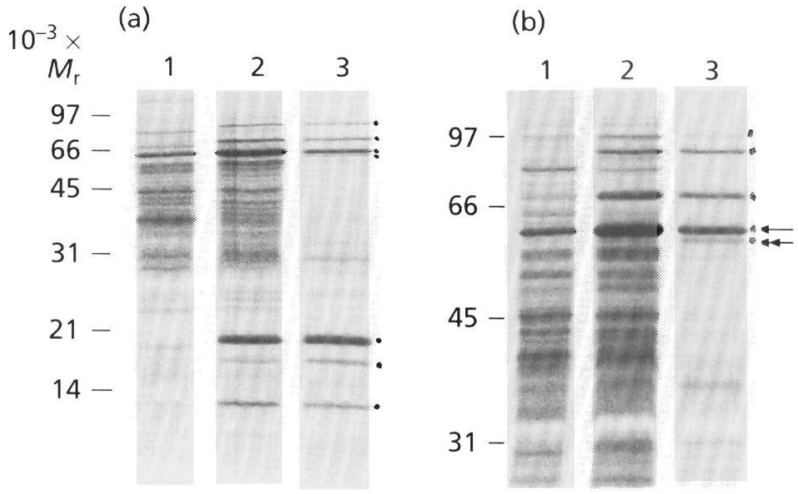

Fig. 1

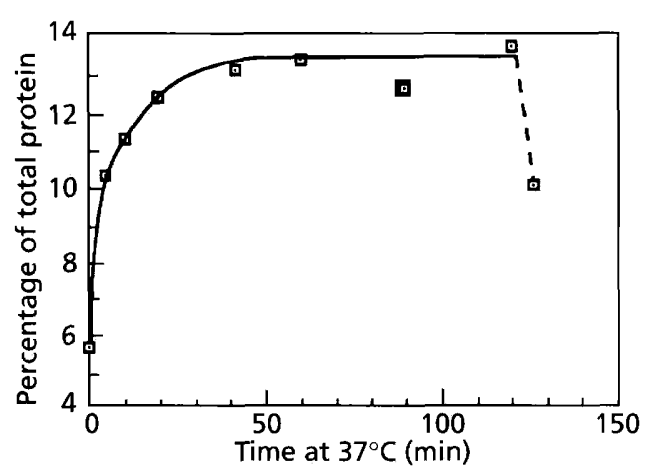

Fig. 2

Fig. 1. Autoradiograph of the protein profile at $28^{\circ} \mathrm{C}$ (lane 1), and after a $10 \mathrm{~min}$ heat shock at $37^{\circ} \mathrm{C}$ (lane 2 ) and $45^{\circ} \mathrm{C}$ (lane 3). Newly induced proteins are indicated by dots. The proteins with $M_{r} 60000$ and 58000 are indicated by single and double arrows respectively in (b). Gels were $12.5 \%$ (a) or $7.5 \%$ (b) polyacrylamide. Positions of $M_{r}$ weight markers are indicated.

Fig. 2. Densitometric scan of the band at $M_{\mathrm{r}} 60000$ in SDS-PAGE gels of heat shocked $R$. leguminosarum. The bacteria were pulse-labelled for $10 \mathrm{~min}$ at the indicated times after heat shock $\left(37^{\circ} \mathrm{C}\right)$. The final time point was taken 6 min after shifting the culture back to $28^{\circ} \mathrm{C}$.

\section{RESULTS}

\section{Effect of temperature on protein synthesis in $R$. leguminosarum}

The effect of heat shock on protein synthesis in $R$. leguminosarum was determined by labelling proteins with $\left[{ }^{35} \mathrm{~S}\right]$ methionine. A $10 \mathrm{~min}$ heat shock at $37^{\circ} \mathrm{C}$ resulted in the increased synthesis of proteins with $M_{\mathrm{r}}$ about 90000 , $79000,60000,58000,19000,17000$ and 13000 (Fig. 1). A similar but less marked response was also seen after temperature shift to $34^{\circ} \mathrm{C}$ (data not shown). Increasing the temperature of the heat shock to $45^{\circ} \mathrm{C}$ resulted in the inhibition of most protein synthesis (Fig. 1).

The kinetics of the heat shock response was examined by labelling cultures of $R$. leguminosarum with $\left[{ }^{35} \mathrm{~S}\right]$ methionine for 10 min at various times after heat shock at $37^{\circ} \mathrm{C}$. A final point was also taken 6 min after returning the cultures to $28^{\circ} \mathrm{C}$. The labelled protein profiles were analysed by densitometric scanning of the autoradiographs. This showed that the levels of synthesis of the heat shock proteins rose rapidly, and remained high $120 \mathrm{~min}$ after heat shock. The scan of the band corresponding to a protein with $M_{\mathrm{r}} 60000$ is shown as an example (Fig. 2). Shortly after temperature shift-down, the levels of heat shock protein synthesis also dropped (last point on Fig. 2).

A monoclonal antibody (IA1) against the $M$. bovis Cpn60 protein cross-reacted with a protein with $M_{\mathrm{r}} 60000$ in $R$. leguminosarum. The cross-reactivity with this protein was markedly less strong than with the E. coli homologue (data not shown). However, two proteins of $M_{\mathrm{r}} 58000$ and 60000 cross-reacted with both polyclonal and monoclonal antisera (4-3F) raised against E. coli Cpn60 in this laboratory (data not shown and Fig. 3). One other monoclonal antibody $(4-10 \mathrm{H})$ raised against the E. coli Cpn60 also weakly cross-reacted with the 58000 as well as the 60000 species. No other cross-reactivity was detected between these reagents and the smaller $R$. leguminosarum heat shock proteins, making it unlikely that these proteins are processed forms of Cpn60 as are seen in Streptomyces spp. (Guglielmi et al., 1991).

Immunoprecipitation experiments were carried out to determine whether the $\left[{ }^{35} \mathrm{~S}\right]$ methionine-labelled proteins which were induced upon heat shock were identical to those which cross-reacted with the monoclonal antisera. As seen in Fig. 4, a protein of $M_{\mathrm{r}} 60000$ was precipitated from cells grown at $28{ }^{\circ} \mathrm{C}$, and more was precipitated after the cells were heat shocked at $37^{\circ} \mathrm{C}$. The 58000 protein was not precipitated under these conditions. As it was possible that the cells were not completely lysed by the gentle freeze-thaw method, we modified the lysis procedure by the addition of SDS ( $1 \%$ final concentration) prior to immunoprecipitation. This resulted in the immunoprecipitation of proteins of $M_{\mathrm{r}} 60000$ and 58000 , in addition to other unidentified proteins (Fig. 4).

\section{Identification of cpn60 homologues in $R$. leguminosarum}

Hybridization of an E. coli cpn60 probe to a Southern blot 


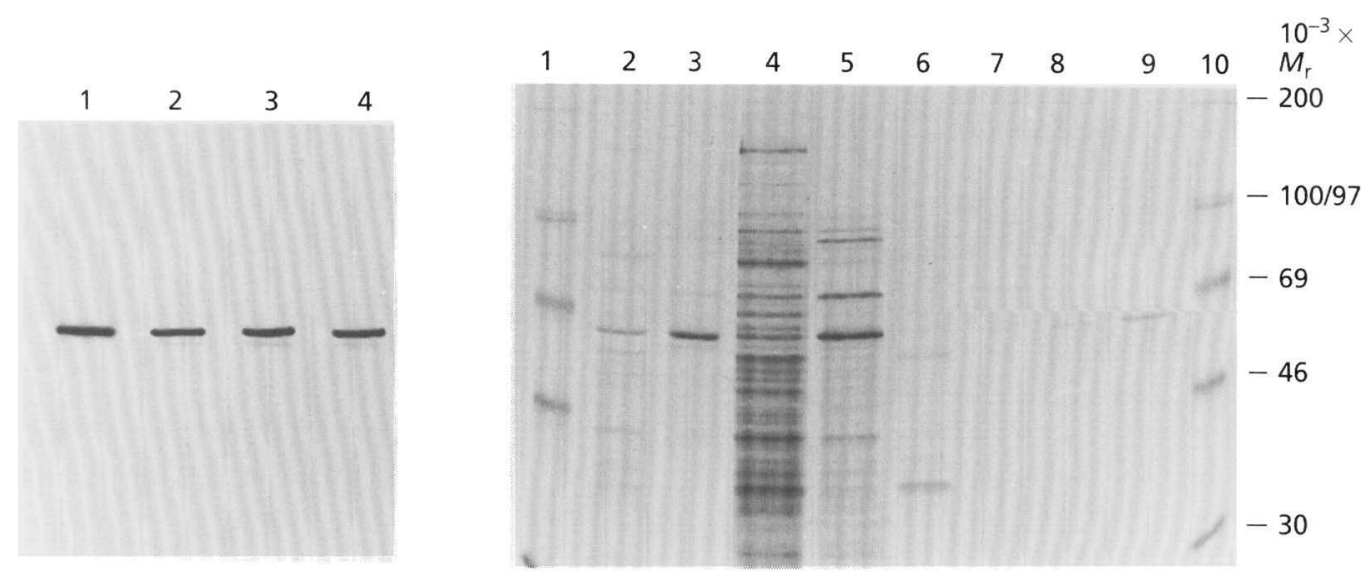

Fig. 3

Fig. 4

Fig. 3. Immunoblot with monoclonal antibody $4-3 \mathrm{~F}$ against total protein from $E$. coli (lane 1 ) and $R$. leguminosarum grown at $28^{\circ} \mathrm{C}$ (lane 2), then heat shocked at $37^{\circ} \mathrm{C}$ (lane 3) or $45^{\circ} \mathrm{C}$ (lane 4).

Fig. 4. Autoradiograph of immunoprecipitated $R$. leguminosarum proteins. Lanes 1 and $10,{ }^{14} \mathrm{C}$-labelled $M_{\mathrm{r}}$ markers, sizes indicated. Protein extracts in lanes 2, 4, 6 and 8 were from cells grown at $28^{\circ} \mathrm{C}$, whereas extracts in lanes $3,5,7$ and 9 were from cells grown at $28^{\circ} \mathrm{C}$ and heat shocked at $37^{\circ} \mathrm{C}$. Proteins in lanes 2 and 3 were extracted from cells lysed with SDS and immunoprecipitated with 4-3F. Lanes 4-9 were from the standard immunoprecipitation protocol: lanes 4 and 5, total cell protein extract; lanes 6 and 7 cell lysate (soluble fraction); and lanes 8 and 9, proteins immunoprecipitated with 4-3F.

containing total EcoRI-digested DNA from R. leguminosarum showed two bands, suggesting the presence of at least two cpn60 homologues in this organism (data not shown). The cloning (see below) and restriction mapping of one of these homologues ruled out the possibility that the two bands were due to the presence of an EcoRI site in a single cpn60 homologue.

A R. leguminosarum cpn60 specific probe was obtained by restriction digestion of $\mathrm{pC} 15$, the plasmid containing the cloned cpn60 homologue (see below). The use of this probe on $\mathrm{R}$. leguminosarum DNA revealed the presence of a third $\operatorname{cpn} 60$ homologue which had not previously been identified (Fig. 5). The three cpn60 homologues which were detected with this probe consistently exhibited different levels of intensity, indicative of varying degrees of homology, but hybridization was seen to all three bands even at very high stringency $(0 \cdot 1 \times \mathrm{SSPE}$, $0 \cdot 1 \%$ SDS, $\left.42{ }^{\circ} \mathrm{C}\right)$. None of the three genes were on the sym plasmid, as identical hybridization patterns were observed with three strains which contained either the viciae, phaseoli or no sym plasmid (data not shown) but were otherwise isogenic.

\section{Isolation and characterization of a $\boldsymbol{R}$. leguminosarum cpn60 homologue}

A plasmid (designated pC15) containing one of the $R$. leguminosarum cpn60 homologues was isolated as described. This plasmid was shown to contain a $3.5 \mathrm{~kb}$ insert. Sequence analysis revealed that an ORF with high homology to other prokaryotic cpn60 genes was immediately downstream of one of the EcoRI sites at the end

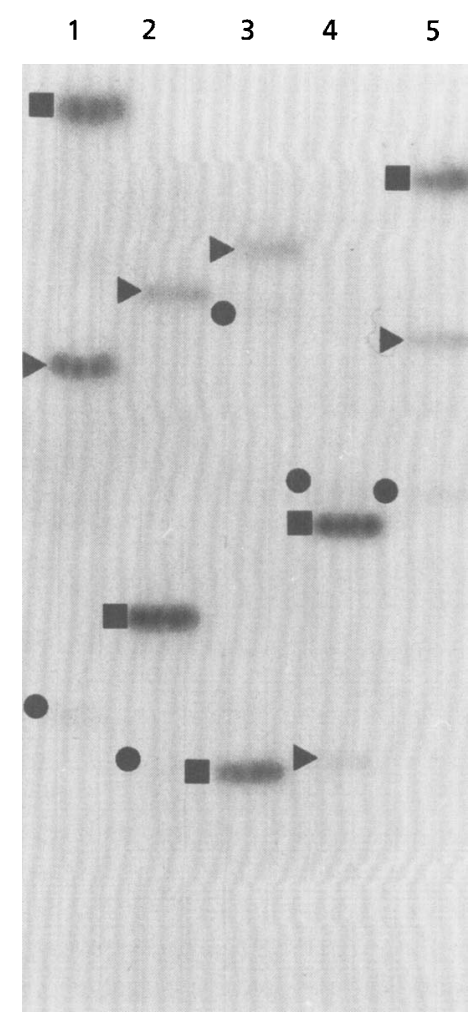

Fig. 5. Southern blot of digested genomic DNA from 8401/pRL1 probed with the cpn60 fragment from pC15. The enzymes used were BamHI (lane 1), EcoRI (lane 2), Hindlll (lane 3), Pstl (lane 4) and Smal (lane 5). Strong, medium and weakly hybridizing bands are indicated with $\mathbf{a} \mathbf{\square}, \boldsymbol{a n d} \boldsymbol{\bullet}$, respectively. 
GAATTCAGGAgTTAAGAATATGGCATCTAAAGAAATCAAGTTTGGCCGCACCGGCCGCGAAAAGATGCTGCGTGGCGTCGACATTCTCGCCGATGCAGTO

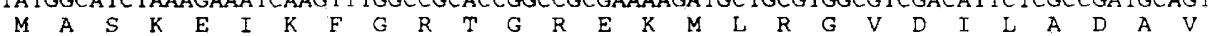

11

130

150

170

190

AAGGTCACGCTTCGGCCCGAAGGGCCGTAACGTCATCATCGACAAGTCCTTCGGCGCTCCGCGCATCACCAAGGACGGCGTTTCGGTCGCCAAGGAGATCG $\begin{array}{llllllllllllllllllllllllllllllllll}K & V & T & L & G & P & K & G & R & N & V & I & I & D & K & S & F & G & A & P & R & I & T & K & D & G & V & S & V & A & K & E & I & E\end{array}$

250

270

AACTCGAAGACAAGTTCGAAAACATGGGCGCCCAGATGGTCCGCGAAGTTGCTTCGAAGÁCCAACGACATCGCCGGCGACGGCACCACGACTGCAACCGT

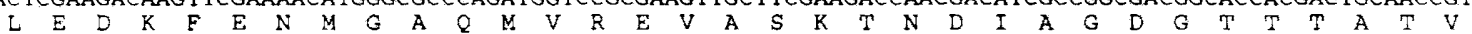
310 330 350

370

TCTTGCCCAGGCGATCGTTCGCGAAGGCAACAAGGCCGTTGCCGCCGGCAंTGAACCCGATGGACCTGAAGCGCGGCATCGATCTTGCTGTTGCTGACGTC

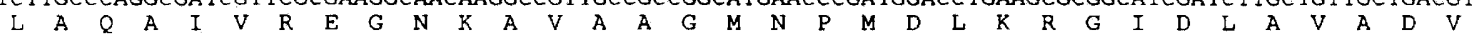
410
430
450
470
490

GTGAAGGATCTCCAGGCCAÄGCCAAGAAGATCTCCACCTCGGAAGAAGTTGCACAGGTCGGCACGAT"TTCGGCCAATGGCGACAAGCAGGTCGGTCTCG $\begin{array}{llllllllllllllllllllllllllllllllll}V & K & D & L & Q & A & K & A & K & K & I & S & T & S & E & E & V & A & Q & V & G & T & I & S & A & N & G & D & K & Q & V & G & L & D\end{array}$

$\begin{array}{llll}510 & 530 & 550 & 570\end{array}$

ACATTGCTGÁAGCCATGCAGAAGGTCGGCAACGAAGGCGTCATCACGGTTGAAGAAGCCÁAGACCGCCGAAACCGAACTCGAAGTCGTCGAAGGCATGCA

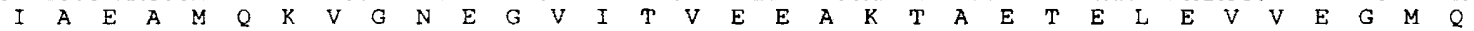
610
630
650
670
690

GTTCGACCGCGGCTACCTCÄGCCCCTACTTCGTGACCAACCCGGAAAAGÄTGATCGCAGÁCCTCGAAGATGTCTTCATTCTCCTTCACGÄGAAGAAGCTC

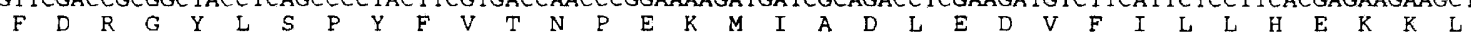

730

750

770

790

TCGAACCTGCAGTCGATGCTCCCGGTTCTCGAAGCTGTCGTCCAGACCGGCAAGCCGCTCCTCATCGTCGCTGAAGACGTAGAAGGCGAAGCCCTCGCAAं

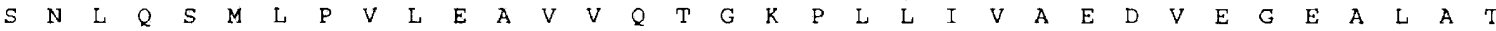

$\begin{array}{lllll}810 & 830 & 850 & 870 & 890\end{array}$

CGCTCGTCGTCAACAAGCTGCGCGGTGGCCTCAAGATCGCTGCCGTCAAGGCGCCCGGCTITCGGCGATCGCCGCAAGCGCATGCTCGAAGACATCGCCAT

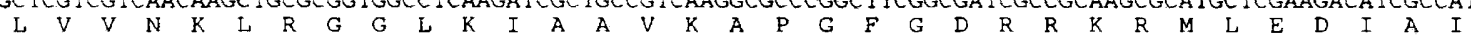

$\begin{array}{rrrr}910 & 930 & 950 & 970\end{array}$

CCTGACGGGCGGCACTGTCATCTCTGAAGATCTCGGCATCAAGCTCGAATCCGTCACGCTCGACATGCTCGGCCGTGCCAAGAAGGTTTCGATCTCCAAG $\begin{array}{lllllllllllllllllllllllllllllllllllll}L & T & G & G & T & V & I & S & E & D & L & G & I & K & L & E & S & V & T & L & D & M & L & G & R & A & K & K & V & S & I & S & K & \end{array}$
1010
1030
1050
1070
1090

GAAAACACCÁCGATCGTCGÄCGGTTCGGGCGCCAAGACCGACATCGAAGGCCGTGTTGCCCAGATCAAGGCTCAGATCGAAGAAACCACCTCCGACTACG

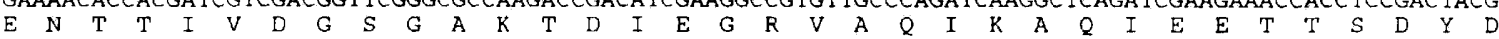
1110
1130
1150
1170
1190

ACCGCGAGAAGCTGCAGGAACGCCTTGCCAAGCTCGCTGGCGGCGTTGCCGTCATCCGCGTCGGCGGCTCGACGGAAGTTGAAGTGAAGGAAAAGAAGGA $\begin{array}{lllllllllllllllllllllllllllllllll}R & E & K & L & Q & E & R & L & A & K & L & A & G & G & V & A & V & I & R & V & G & G & S & T & E & V & E & V & K & E & K & K & D\end{array}$
1210
1230
1250
1270
1290

CCGCATCGACGACGCGCTCAAAGCGACCCGCGCTGCTGTTCAGGAAGGCÄTCGTCCCCGGCGGCGGTATCGCTCTCGCTCGCTCCTCCACGAAGATCACC

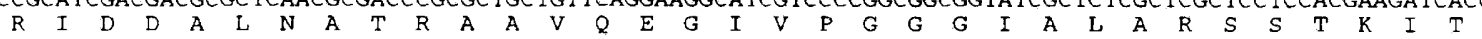
1310
1330
1350
1370
1390

GTCAAGGGTGCAAACGACGACCAGGAAGCCGGCATCAACATCGTTCGCCGCGCCCTGCAGTCGCTCGTTCGTCAGATCGCTGAAAACGCAGGCGACGAAG

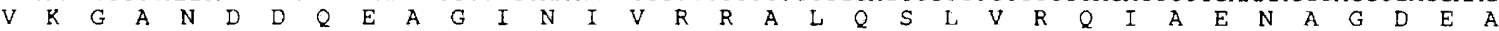
1410
1430
1450
1470
1490

CCTCGATCGTTGTCGGCAAGGTCCTCGACAAGAACGAAGACAACTTCGGCTACAACGCCCAGACATCCGAATATGGCGACATGATCGCCAंTGGGTATCGT

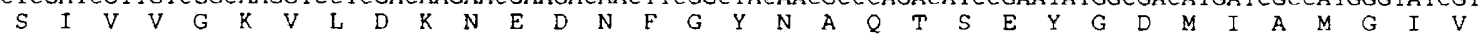
1510
1530
1550
1570
1590

CGACCCGCTCAAGGTCGTTCGCACGGCGCTGCAGAACGCCGCTTCTGTCGCATCGCTGCTGATCACCACCGAAGCCATGATCGCCGAACTGCCGAAGAAG

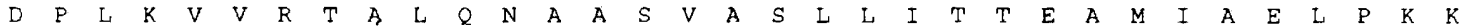

$1610 \quad 1630 \quad 1650$

GATGCCCCAGCTGGCATGCCGGGCGGCATGGGCGGCATGGGCGGTATGGACATGATGTGÁTCGG

$D$ A P A G M P G G M G G M G G M D M M *

Fig. 6. Nucleotide and deduced amino acid sequences of the $R$. leguminosarum cpn60 homologue $C 15$. The nucleotide sequence is numbered from the first base of the upstream EcoRI site used to clone the fragment. 
Identity (\%) Similarity (\%)

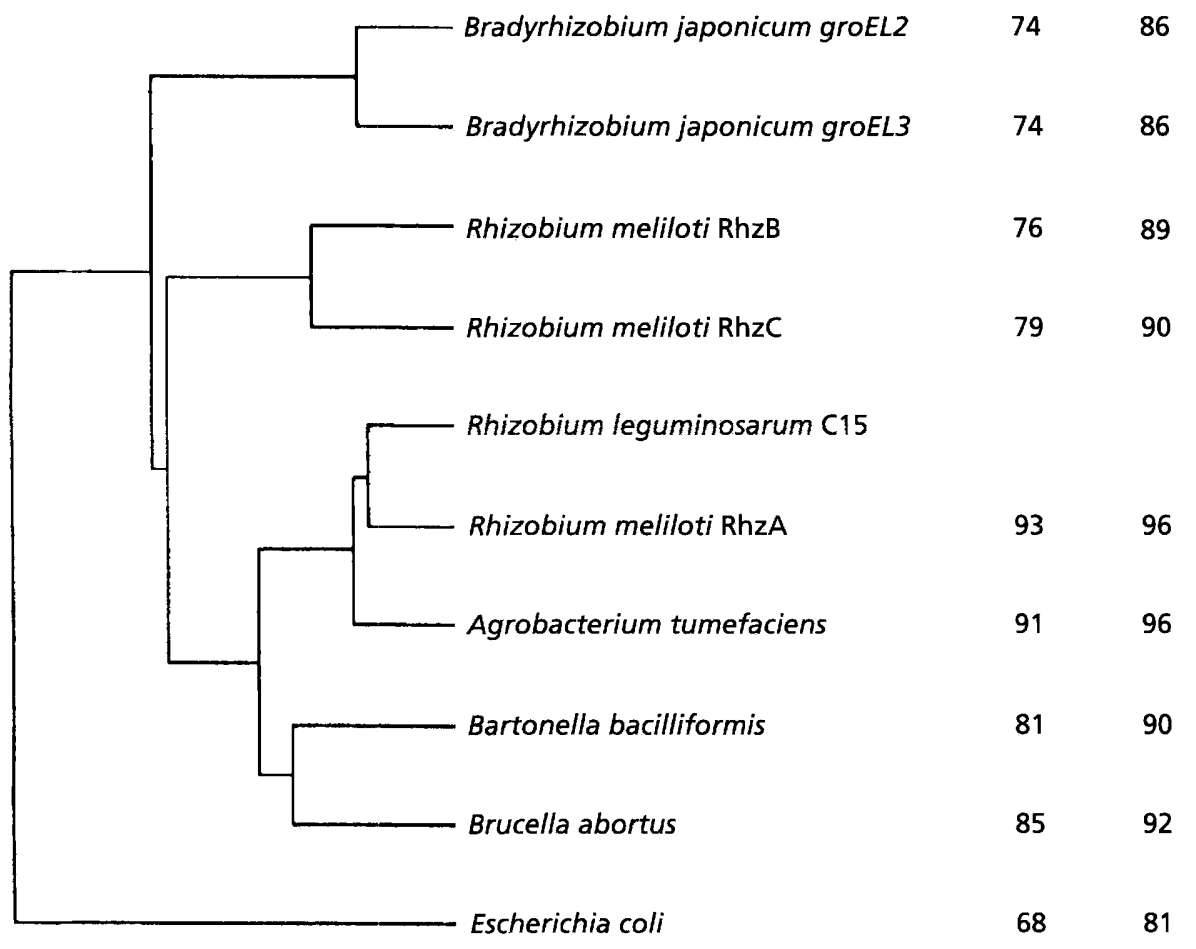

Fig. 7. Dendrogram showing the relationship between R. leguminosarum Cpn60 C15 and selected Cpn60 homologues, based on a multiple sequence alignment (University of Wisconsin GCG package 'Pileup'). (pn60 sequences with the closest homology are shown: R. meliloti RhzA, B and C (Rusanganwa \& Gupta, 1993), A. tumefaciens (Segal \& Ron, 1993), B. abortus (Gor \& Mayfield, 1992), B. bacilliformis (Y. Xu and others, unpublished results; GCG accession number $\mathrm{Gb}-\mathrm{Ba}$ :BaBaobb63a) and B. japonicum (Fischer et al., 1993). The $E$. coli Cpn60 sequence is also included (Hemmingsen et al., 1988). The percentage identity and similarity of the Cpn60 proteins to $R$. leguminosarum C15 are shown.

of the cloned fragment. The insert was subcloned as described, and the DNA sequence determined on both strands (Fig. 6). Translation of the largest ORF would give a protein of 546 amino acids, with an $M_{\mathrm{r}}$ of 57865 and a $\mathrm{pI}$ of 4.97 . The predicted amino acid sequence showed high homology with other bacterial Cpn60 proteins in the GenBank database, confirming that this was a cpn60 homologue. We refer to this gene as C15 throughout this paper, pending a complete characterization of all the cpn60 and $c p n 10$ genes in this organism. The highest degree of indentity was seen with one of the Cpn60 proteins of Rhizobium meliloti (RhzA). Other related proteins, including the $E$. coli $C$ pn 60 protein, are shown in the dendrogram (Fig. 7) with their relative identities and similarities to $\mathrm{C} 15$, and are aligned with the sequence described here in Fig. 8.

Two further clones which hybridized to the cloned $c p n 60$ homologue were isolated from a size fractionated PstI library by probing with the pC15 insert. The first (pB45) contained a $5 \mathrm{~kb}$ insert; preliminary sequence data from one end showed that it includes the $5^{\prime}$ region of a $\operatorname{cpn} 60$ gene distinct from that on $\mathrm{C} 15$, being closer in homology to $R$. meliloti $\mathrm{RhzC}$ (data not shown). A deletion was constructed in this plasmid that enabled the determination of the sequence upstream of the $\operatorname{cpn} 60$ gene, and this revealed the presence of sequences homologous to $c p n 10$. The second PstI clone (pD98) contained a $4.7 \mathrm{~kb}$ insert. Preliminary sequence data (obtained using internal primers designed for the $\mathrm{C} 15$ homologue) showed that this contained the $5^{\prime}$ region of a third $c p n 60$ gene, again with a $\operatorname{cpn} 10$ gene upstream. Sequence derived from the termini of this cloned insert showed that unrelated sequences flank the $c p n 60 / 10$ genes. It is therefore likely that a complete operon has been isolated on this fragment. The cpn 60 gene in this clone is closely related to $\mathrm{R}$. meliloti $\operatorname{rbz} A$, but restriction mapping and DNA sequence analysis of the insert shows that it is distinct from the $\mathrm{C} 15$ homologue (data not shown). A third clone which hybridized with the $\mathrm{C} 15$ probe was isolated from the Pst $\mathrm{I}$ library. It contained a $2 \mathrm{~kb}$ insert, and DNA sequence analysis showed that it contained the downstream end of the $\mathrm{C} 15$ gene.

\section{Expression of C15 in E. coli}

The R. leguminosarum cpn60 homologue $\mathrm{C} 15$ was expressed in $E$. coli under the control of the lac promoter on the plasmid pSU9, induced by the addition of IPTG to the medium (Fig. 9). N-Terminal sequence analysis of the first 


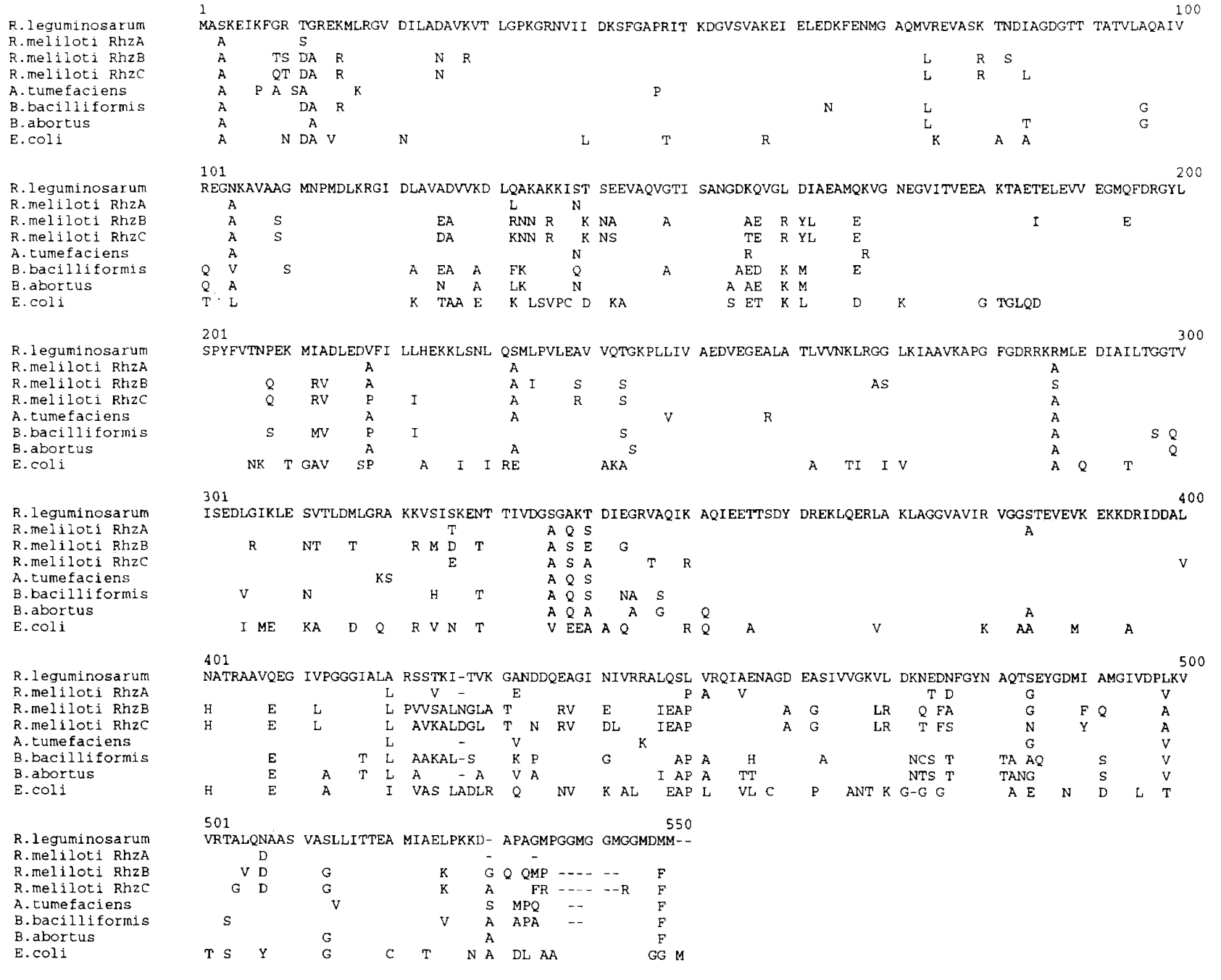

Fig. 8. Amino acid sequence alignment of $R$. leguminosarum Cpn60 C15 with selected Cpn60 homologues (as Fig. 7). Only amino acids which are non-identical with the $R$. leguminosarum sequence are shown.

nine amino acids of the over-expressed protein confirmed its identity as the $R$. leguminosarum cpn60 gene product, initiated at the correct methionine. Native gradient gel electrophoresis also demonstrated that the foreign Cpn60 migrated as an oligomer of approximately the same $M_{\mathrm{r}}$ as the native $E$. coli protein (data not shown). Overexpression of $\mathrm{C} 15$ from this plasmid failed to restore growth at $42{ }^{\circ} \mathrm{C}$ in an $E$. coli strain carrying a ts mutation in the $c p n 60$ gene (SF103), whereas expression of the $E$. coli cpn60 cloned into pSU18 (D. Olden, pers. comm.) restored growth at the non-permissive temperature. The temperature-sensitive mutation in this strain also blocks bacteriophage $\lambda$ growth even at $37{ }^{\circ} \mathrm{C}$. Bacteriophage $\lambda$ growth on SF103 was not restored by the expression of the $R$. leguminosarum gene, but was restored by the plasmid-borne E. coli cpn60 after induction with IPTG.

\section{DISCUSSION}

The results presented here provide evidence that $R$. leguminosarum contains and expresses multiple Cpn60 proteins. Pulse labelling experiments showed the induction of novel proteins in heat shocked $R$. leguminosarum. Enhanced synthesis of proteins at approximate $M_{\mathrm{r}} 90000,70000$ and 60000 (corresponding to stress proteins Hsp90, DnaK and Cpn60) is a conserved feature of the heat shock response of many organisms (Lindquist \& Craig, 1988). Proteins with these $M_{\mathrm{r}}$ values were seen in R. leguminosarum; in addition, a species of $M_{\mathrm{r}} 58000$ was also observed. We believe both the 58000 and 60000 proteins to be Cpn60 homologues due to their crossreactivity with both polyclonal and monoclonal antisera, although we cannot completely rule out the possibility that the 58000 band represents a truncated or slightly degraded form of the 60000 protein. The identity of some of the other strongly heat shock induced proteins seen here $\left(M_{\mathrm{r}} 19000\right.$ and 17000$)$ are unknown; the possibility that they might be processed forms of Cpn60 as is seen in Streptomyces albus (Guglielmi et al., 1991) is rendered less likely by the failure of anti-Cpn60 serum to cross-react with them. The heat shock induced protein with an apparent $M_{\mathrm{r}}$ of 13000 may be one of the Cpn10 


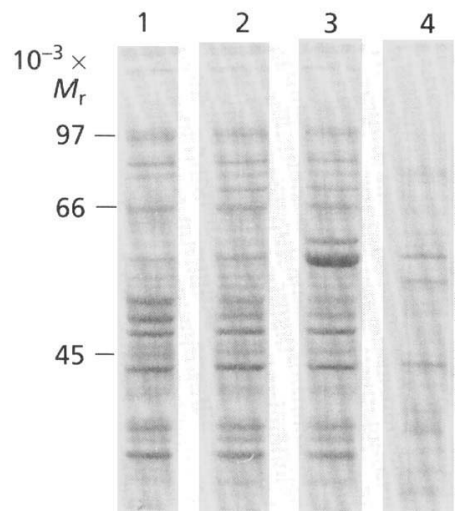

Fig. 9. Expression of $R$. leguminosarum cpn60 in $E$. coli. Coomassie blue stained SDS-PAGE gel of protein extracted from E. coli (lane 1), E. coli containing PC15 without IPTG (lane 2), and plus IPTG (lane 3), or R. leguminosarum (lane 4).

homologues which we have identified by sequence analysis.

Our data indicate that $R$. leguminosarum contains at least three $\operatorname{sn} 60$ genes, and we have completely sequenced one of these. We have demonstrated that none of these genes are located on the sym plasmid, but we have not addressed the possibility that one or more copies may be located on a mega plasmid, as is seen with R. meliloti (Rusanganwa \& Gupta, 1993). Although we cannot currently rule out the possibility that one or more of these copies may be pseudogenes, evidence for the expression of two Cpn60 homologues has been demonstrated by Western blotting and by immunoprecipitation. It is not clear whether the proteins of $M_{\mathrm{r}} 60000$ and 58000 seen in R. leguminosarum each represents a gene product with the third gene either not expressed or expressed at undetectable levels, or whether two Cpn60 proteins of very similar $M_{\mathrm{r}}$ are superimposed in one of the bands. Attempts to resolve the bands into more than one spot using two-dimensional electrophoresis have not been successful (data not shown).

These results are similar to those reported recently for other members of the Rhizobiaceae: Bradyrbizobium japonicum and $R$. meliloti have both been shown to possess multiple cpn60 genes (Fischer et al., 1993; Rusanganwa \& Gupta, 1993). Three cpn60 homologues from R. meliloti have been cloned and sequenced, and two copies have been mapped to the mega plasmids (Rusungawa et al., 1993). In B. japonicum, two of the five homologues have been mapped to the chromosome, one being close to symbiotic cluster II and under NifA regulation (Kundig et al., 1993; Fischer et al., 1993). In all the examples so far reported of bacteria where multiple cpn 60 genes are found, not all the $c p n 60$ genes are organized with an upstream $c p n 10$ gene (as is invariably seen when only one $c p n 60$ gene is present). In the current study, two of the three $c p n 60$ genes identified have $c p n 10$ genes upstream; the upstream region of the third $\operatorname{cpn} 60$ gene $(\mathrm{C} 15)$ has not yet been cloned.

Expression of the cloned $R$. leguminosarum $C p n 60$ from the lac promoter in E. coli did not allow complementation of the cpn 60 ts mutation in SF103 or permit $\lambda$ growth in this strain, despite the induced polypeptide initiating at the correct methionine and appearing to oligomerize. Complementation was seen when the E. coli cpn60 gene was expressed from the same plasmid under plac control. Complementation of defective $c p n 60$ alleles in $E$. coli is generally only seen with Cpn60 proteins with a high level of identity to the E. coli protein (for example Chromatium vinosum, 75.5\% identical; Ferreyra et al., 1993), or the bacterial endosymbiont of Acyrthosiphon pisum (85.8\% identical; Ohtaka et al., 1992), although it is interesting to note that the $c p n 60$ gene from Bacillus stearothermophilus can complement a cpn60 ts mutation in E. coli despite only having $61 \%$ identity to the $E$. coli gene (Schoen \& Schumann, 1993). Failure to complement in the case of the $R$. leguminosarum gene is not due to poor protein expression or failure to assemble into an oligomer, and may be due to the inability of the $R$. leguminosarum protein to interact with the E. coli Cpn10 protein. We are currently investigating this further.

Cpn60 proteins have been shown to interact with a wide variety of proteins, which they appear to bind in an unfolded or partially folded state (Ellis \& van der Vies, 1991; Zeilstra-Ryalls et al., 1991; Saibil \& Wood, 1993). Because of this low specificity, the presence of multiple copies of cpn60 genes in several bacteria is somewhat unexpected. It may be the case that the existence of multiple genes is simply one way in which the organism can increase the total levels of Cpn60 protein in the cell at times of stress, or under other conditions when the protein is needed at high levels. Alternatively, different Cpn60 proteins may serve different functions. For example Rhizobium species, in addition to having a free-living existence, are also endosymbiotic. The formation of root nodules is a complex process involving the synthesis of many new bacterial proteins, both for the formation of the bacteroid and subsequently the enzymic fixation of nitrogen. In connection with this, it has been shown that the production of nitrogenase components either in Klebsiella pneumoniae or $E$. coli is much enhanced by (and may require) the presence of Cpn60 (Govezensky et al., 1991). The possibility exists that one or more of the Cpn60 protein complexes are specialized for particular functions in the development of the endosymbiont. It is not yet known for any of the organisms which express more than one Cpn60 protein whether the proteins form mixed multimers or homo-oligomeric complexes; this is also not known for chloroplasts which are the first organelles in which the function of these proteins were recognized (Hemmingsen et al., 1988) and which contain two cpn60 homologues. It will be of great interest to follow the expression of the diverse $c p n 60$ genes as the endosymbiotic bacteria differentiate. Complete characterization, including mutagenesis, of the three $R$. leguminosarum cpn 60 genes will be necessary to determine whether they are all 
functional, whether they are differentially regulated, and whether they have different roles within the bacterial cell.

\section{Note added in proof}

We have now completed the cloning of the region upstream of the $\mathrm{C} 15$ gene and confirmed that this region contains a cpn10 gene. We thus suggest the following nomenclature for $R$. leguminosarum chaperone genes: cpn60-1 (for pC15); cpn60-2 (for pD98) and cpn60-3 (for $\mathrm{B} 45)$, with the cognate $c p n 10$ genes being referred to as cpn10-1, cpn10-2 and cpn10-3 respectively.

\section{ACKNOWLEDGEMENTS}

We are grateful to $\mathrm{Dr}$ A. Downie (John Innes Institute, Norwich) for provision of bacterial strains and helpful advice and discussions, to Dr J. de Bruyn (Institut Pasteur du Brabant, Brussels) for monoclonal antibody against $M$. bovis $\mathrm{Cpn} 60$, to A. Ivic (University of Birmingham) for monoclonal antibodies against E. coli Cpn60, and to Professor C. Georgopoulos (Centre Medical Universitaire, Geneva) for the provision of a $c_{p n} 60$ ts strain. E. J.W. is an Agricultural and Food Research Council postdoctoral fellow.

\section{REFERENCES}

Ausubel, F. M. (1987). Current Protocols In Molecular Biology. New York: Wiley Interscience.

Badcoe, I. G. V., Smith, C. J., Wood, S., Halsall, D. J., Holbrook, J. J., Lund, P. \& Clarke, A. R. (1991). Binding of a chaperonin to the folding intermediates of lactate dehydrogenase. Biochemistry $\mathbf{3 0}$, 9195-9200.

Beringer, J. E. (1974). R-Factor transfer in Rhizobium leguminosarum. J Gen Microbiol 84, 188-198.

Buchner, J., Schmidt, M., Fuchs, M., Jaenicke, R., Rudolph, R., Schmid, F. X. \& Kiefhaber, T. (1991). GroE facilitates refolding of citrate synthase by suppressing aggregation. Biochemistry 30, 1586 1591.

Del Sal, G., Manfioletti, G. \& Schneider, C. (1989). The CTABDNA precipitation method - a common mini-scale preparation of template DNA from phagemids, phages or plasmids suitable for sequencing. Biotechniques 7, 514-519.

De Wit, T. F. R., Bekelie, S., Osland, A., Miko, T. L., Hermans, P. W. M., van Soolingen, P., Drijfhout, J-W., Schoeningh, R., Janson, A. A. M. \& Thole, J. E. R. (1992). Mycobacteria contain two groEL genes: the second Mycobacterium leprae groEL gene is arranged in an operon with groES. Mol Microbiol 6, 1995-2007.

Ellis, R. J. \& van de Vies, S. M. (1991). Molecular chaperones. Annu Rev Biochem 60, 321-347.

Ferreyra, R. G., Soncini, F. C. \& Viale, A. M. (1993). Cloning, characterization, and functional expression in Escherichia coli of chaperonin (groESL) genes from the phototrophic sulphur bacterium Cbromatium vinosum. J Bacteriol 175, 1514-1523.

Fischer, H. M., Babst, M., Kaspar, T., Acuna, G., Arigoni, F. \& Hennecke, H. (1993). One member of a groESL-like chaperonin multigene family in Bradyrbizobium japonicum is co-regulated with symbiotic nitrogen fixation genes. EMBO J 12, 2901-2912.

Fisher, M. T. (1992). Promotion of the in vitro renaturation of dodecameric glutamine synthetase from Escherichia coli in the presence of Cpn60 (chaperonin-60) and ATP. Biocbemistry 31, 3955-3963.

Gething, M.-J. \& Sambrook, J. (1992). Protein folding in the cell. Nature 355, 33-45.

Goloubinoff, P., Gatenby, A. A. \& Lorimer, G. H. (1989). GroE heat-shock proteins promote assembly of foreign prokaryotic ribulose bisphosphate carboxylase oligomers in Escherichia coli. Nature 337, 44-47.

Gor, D. \& Mayfield, J. E. (1992). Cloning and nucleotide sequence of the Brucella abortus groE operon. Biochim Biopbys Acta 1130 , $120-122$.

Govezensky, D., Greener, T., Segal, G. \& Zamir, A. (1991). Involvement of GroEL in nif gene regulation and nitrogenase assembly. J Bacteriol 173, 6339-6346.

Guglielmi, G., Mazodier, P., Thompson, C. J. \& Davies, J. (1991). A survey of the heat shock response in four Streptomyces species reveals two groEL-like genes and three GroEL-like proteins in Streptomyces albus. J Bacteriol 173, 7374-7381.

Hemmingsen, S. M., Woolford, C., van der Vies, S. M., Tilly, K., Dennis, D. T., Georgopoulos, C., Hendrix, R. W. \& Ellis, R. J. (1988). Homologous plant and bacterial proteins chaperone oligomeric protein assembly. Nature 333, 330-334.

Holl-Neugebauer, B., Rudolph, R., Schmidt, H. \& Buchner, J. (1991). Reconstitution of a heat-shock effect in vitro: influence of GroE on the thermal aggregation of $\alpha$-glucosidase from yeast. Biochemistry 30, 11609-11614.

Kong, T. H., Coates, A. R. M., Butcher, P. D., Hickman, C. J. \& Shinnick, T. M. (1993). Mycobacterium-tuberculosis expresses two chaperonin-60 homologs. Proc Natl Acad Sci US A 90, 2608-2612.

Kundig, C., Hennecke, H. \& Gottfert, M. (1993). Correlated physical and genetic map of the Bradyrbizobium japonicum 110 genome. J Bacteriol 175, 613-622.

Laminet, A. A., Ziegelhoffer, T., Georgopoulos, C. \& Pluckthun, A. (1990). The E. coli heat-shock proteins GroEL and GroES modulate the folding of $\beta$-lactamase precursor. EMBO $J \mathbf{9}$, 2315-2319.

Lehel, C., Los, D., Wada, H., Gyorgyei, J., Horvath, I., Kovacks, E., Murata, N. \& Vigh, L. (1993). A second groEL-like gene, organized in a groESL operon, is present in the genome of Synechocystis sp. PCC-6803. J Biol Chem 268, 1901-1907.

Lindquist, S. \& Craig, E. A. (1988). The heat-shock proteins. Annu Rev Genet 22, 631-677.

Martinez, E., Bartolome, B. \& de la Cruz, F. (1988). pACYC184derived cloning vectors containing the multiple cloning site and lac $Z$ alpha reporter gene of pUC8/9 and pUC18/19 plasmids. Gene 68, 159-162.

Mendoza, J. A., Rogers, E., Lorimer, G. H. \& Horowitz, P. M. (1991). Chaperonins facilitate the in vitro folding of monomeric mitochondrial thodanese. J Biol Chem 266, 13044-13049.

Ohtaka, C., Nakamura, H. \& Ishikawa, H. (1992). Structures of chaperonins from an intracellular symbiont and their functional expression in Escherichia coli groE mutants. J Bacteriol 174, 18691874.

Rusanganwa, E. \& Gupta, R. S. (1993). Cloning and characterization of multiple groEL chaperonin-encoding genes in Rbizobium meliloti. Gene 126, 67-75.

Saibil, H. \& Wood, S. (1993). Chaperonins. Curr Opin Struct Biol 3, 207-213.

Sambrook, J., Fritsch, E. F. \& Maniatis, T. (1989). Molecular Cloning: 
A Laboratory Manual. Cold Spring Harbor, NY: Cold Spring Harbor Laboratory.

Schoen, U. \& Schumann, W. (1993). Molecular cloning, sequencing, and transcriptional analysis of the groESL operon from Bacillus stearothermophilus. J Bacteriol 175, 2465-2469.

Segal, G. \& Ron, E. Z. (1993). Heat shock transcription of the groESL operon of Agrobacterium tumefaciens may involve a hairpinloop structure. J Bacteriol 175, 3083-3088.

Sherwood, M. T. (1970). Improved synthetic medium for the growth of Rhizobium. J Appl Bacteriol 33, 708-713.

Silhavy, T. J., Berman, M. L. \& Enquist, L. W. (1984). Experiments with Gene Fusions. Cold Spring Harbor, NY: Cold Spring Harbor Laboratory.

Taguchi, H., Konishi, J., Ishii, N. \& Yoshida, M. (1991). A chaperonin from a thermophilic bacterium Thermus thermophilus that controls refoldings of several thermophilic enzymes. $J$ Biol Chem 266, 22411-22418.

Viitanen, P. V., Donaldson, G. K., Lorimer, G. H., Lubben, T. H. \& Gatenby, A. A. (1991). Complex interactions between the chaperonin 60 molecular chaperone and dihydrofolate reductase. Biochemistry 30, 9716-9723.

Viitanen, P. V., Gatenby, A. A. \& Lorimer, G. H. (1992). Purified chaperonin 60 (Cpn60) interacts with the non-native states of a multitude of Eschericbia coli proteins. Protein Sci 1, 363-369.

Zeilstra-Ryalls, J., Fayet, O. \& Georgopoulos, C. (1991). The universally conserved GroE (Hsp60) chaperonins. Annu Rev Microbiol 45, 301-325.

Received 15 July 1993; revised 27 August 1993; accepted 31 August 1993. 